\title{
Methods for Pigeon Pea Seed Storage in Puerto Rico'
}

\author{
M. A. Ellis, E. J. Ravalo, and R. S. Smith ${ }^{2}$
}

\begin{abstract}
Pigeon pea seeds were adjusted to 9,13 , and $17 \%$ moisture, then placed in cloth bags or air tight plastic bags. Seeds at each of the above mentioned moisture levels and container types were stored both under ambient conditions at Mayaguiez and in cold storage $\left(13^{\circ} \mathrm{C}\right)$ at Lajas. After 12-month storage, all treatments in cold storage ranged in percentage seed germination in vitro, emergence in sand, and emergence in the field from $90-92 \%, 88-$ $92 \%$ and $70-72 \%$, respectively. All treatments stored in cloth bags under ambient conditions for 12 months had a percentage seed germination in vitro, emergence in sand, and emergence in the field ranging from $36-37 \%, 32-$ $24 \%$ and $16-17 \%$, respectively. There were no significant differences in percentage germination in vitro or in sand or field emergence between seeds stored under ambient conditions at 9 and $13 \%$ moisture in plastic bags and seeds stored in cold storage. All seeds stored at $17 \%$ moisture in plastic bags were dead after 10 months storage under ambient conditions.
\end{abstract}

\section{INTRODUCTION}

Pigeon pea [Cajanus cajan (L.) Millsp.] is an important agricultural food in Puerto Rico. The Agricultural Experiment Station of the University of Puerto Rico has developed a determinant variety (2B-Bushy) which is better adapted to mechanical harvesting of the green seed. In order to obtain maximum efficiency in mechanical harvesting, uniform stands (plant populations) are required. One of the factors which limits the increased production of pigeon pea in Puerto Rico is a low percentage seed germination and emergence in the field. Poor stands in the field can reduce yields because of inadequate plant populations, as well as reduce the efficiency of harvesting equipment. In order to increase the commercial production of pigeon pea in Puerto Rico, a source of high quality (high percentage germination) seeds must be made available to the growers.

Once high quality seeds have been produced, they must be stored for periods of up to 9 months before being planted. This storage period is critical in the maintenance of good seed germination and seedling vigor. Continuous periods of relatively high temperatures and relative humidity are not conducive to long term seed storage of legume seeds $(4,5,6)$. Conditioned (dehumidified and refrigerated) storage is a very effective method of seed storage in the tropics. However, dehumidified cold storage

\footnotetext{
${ }^{1}$ Manuscript submitted to Editorial Board September 27, 1978.

${ }^{2}$ First and second authors, Dept. of Crop Protection and Dep. of Agri. Engineering, University of Puerto Rico, Mayagüez; third author Dep. of Agronomy, University of Illinois, Urbana. The authors wish to thank Eileen Rosario for technical assitance.
} 
is expensive, and problems of maintenance associated with refrigeration and dehumidification equipment can be serious. Alternative methods of seed storage should be developed, especially for use in less developed countries of the tropics.

This study reports on the effect of initial seed moisture content, storage container type, and storage environment on seed viability of pigeon pea in Puerto Rico.

\section{MATERLALS AND METHODS}

Seeds used in this study were harvested March 15, 1977, from a 5 ha field of pigeon pea (cv. 2B-Bushy) at the Fortuna Substation, Agricultural Experiment Station, University of Puerto Rico. Three samples of 400 seeds were tested for percentage incidence of seedborne fungi and germination in vitro [potato dextrose agar (PDA)]. This assay was conducted in order to determine initial seed quality. All seeds were treated at the rate of $113 \mathrm{~g}$ product $/ 45 \mathrm{~kg}$ seed with the insecticide thiodan $[6,7,8,9$,10,10-hexachloro-1,5,5a,6,9,9a-hexahydro-6,9-methano-2,4,3-benzo(3)-dioxathiepin-3-oxide]. Insecticide treated seeds were divided into lots of 3.5 $\mathrm{kg}$ and adjusted to either 9, 13, or $17 \%$ moisture content (dry weight basis). Seed lots at each moisture content were then placed in cotton. cloth bags or sealed in plastic (polyethylene) bags $.0012 \mathrm{~cm}$ thick. Plastic bags were sealed with plastic tape; care was taken to make sure that bags were air tight. Seed lots at all moisture contents and in both storage containers were placed either under ambient conditions at Mayagüez or in cold storage $\left(13^{\circ} \mathrm{C}\right)$ at the Lajas substation on March 25, 1977.

At 2-mo intervals up to 1 year, seeds from all treatments were tested for percentage incidence of seedborne fungi, germination in vitro, emergence in sand, and moisture content. Three samples of 100 seeds from each lot were surface disinfested: soaked in a $0.25 \%$ solution of sodium hypochlorite for $2.5 \mathrm{~min}$, then in a $70 \%$ solution of ethanol for $2 \mathrm{~min}$, and finally rinsed in sterile distilled water. Surface disinfested seeds were then placed on sterile PDA (4 seed per culture dish) and incubated at $25^{\circ}$ C. After 7 days, the percentage in vitro germination and incidence of seedborne fungi was recorded. Three samples of 100 seeds from each lot were also planted in a sandbench at the Isabela substation. Percentage emergence in sand was recorded after 14 days. The percentage moisture content of each lot was measured with a Dicky John seed moisture tester which was calibrated for use on pigeon pea. After 1 year of storage three replications of 100 seeds from each treatment were planted in the field at the Isabela Substation. One hundred seeds were planted in $3 \mathrm{~m}$ rows 65 $\mathrm{cm}$ apart in a completely randomized design. Field emergence was recorded after 21 days. 


\section{RESULTS AND DISCUSSIONS}

The seeds used in this study were of high quality prior to being placed in storage. The mean percentage in vitro germination prior to storage was $94 \%$ with $15 \%$ of the seeds containing internally seedborne fungi.

The initial moisture content of all seeds stored in air-tight plastic bags was maintained at plus or minus .5\% for 1 year. Moisture of seeds placed in cloth bags under ambient and cold storage conditions was 16.5 and $13.5 \%$, respectively, after 4 -month storage, and this moisture content (plus or minus .5\%) was maintained for 1 year.

TABLE 1.-Effect of seed moisture content, storage container, storage environment, and time on percent seed germination in vitro (PDA), emergence in sand and field emergence of pigeon pea

\begin{tabular}{|c|c|c|c|c|c|c|c|c|c|c|c|c|c|}
\hline \multirow{2}{*}{ Storage ${ }^{l}$ treatment } & \multicolumn{13}{|c|}{$\begin{array}{l}\text { Percent }{ }^{2} \text { seed germination in vitro (GI), emergence in sand (E), and field emergence } \\
\qquad(\mathrm{FE}) \text { at various sampling times in months (mo). }\end{array}$} \\
\hline & \multicolumn{2}{|c|}{$2 \mathrm{mo}$} & \multicolumn{2}{|c|}{$4 \mathrm{mo}}$. & \multicolumn{2}{|c|}{$6 \mathrm{mo}$} & \multicolumn{2}{|c|}{$8 \mathrm{mo}$} & \multicolumn{2}{|c|}{$10 \mathrm{mo}$} & GI & $12 \mathrm{mo}$ & $\mathrm{FE}^{:}$ \\
\hline $9-\mathrm{A}-\mathrm{C}$ & 95 & 93 & 93 & 88 & 72 & 66 & 63 & 59 & 53 & 50 & 37 & 32 & 19 \\
\hline $13-\mathrm{A}-\mathrm{C}$ & 9 & 93 & 93 & 87 & 71 & 66 & & 55 & & 4 & 36 & 4 & 16 \\
\hline $17-\mathrm{A}-\mathrm{C}$ & 94 & 93 & 92 & 87 & 73 & 65 & 62 & 54 & 51 & 50 & 36 & 3 & 17 \\
\hline 9-A-P & 94 & 93 & 94 & 92 & 93 & 91 & 92 & 91 & 91 & 89 & 91 & 91 & 73 \\
\hline 13-A-P & 94 & 92 & 92 & 92 & 94 & 92 & $9:$ & 90 & 92 & 90 & 91 & 91 & 72 \\
\hline 17-A-P & 89 & 88 & 72 & 68 & 41 & 34 & 1 & & & 0 & 0 & 0 & 0 \\
\hline 9-CS-C & 93 & 92 & 93 & 90 & 93 & 89 & 91 & 90 & 90 & 90 & 91 & 90 & 72 \\
\hline 13-CS-C & 94 & 93 & 92 & 92 & 92 & 89 & 90 & 8 & 91 & 91 & 92 & 92 & 71 \\
\hline 17-CS-C & 93 & 92 & 92 & 9 & 93 & 88 & 91 & 8 & 90 & 89 & 91 & 89 & 69 \\
\hline 9-CS-P & 92 & 93 & 94 & 91 & 92 & 92 & 90 & 90 & 92 & 92 & 92 & 90 & 70 \\
\hline 13-CS-P & 92 & 92 & 92 & 9 & 93 & 91 & 92 & 91 & 91 & 91 & 91 & 88 & 72 \\
\hline 17-CS-P & 93 & 93 & 93 & 91 & 93 & $9 \mathrm{I}$ & 89 & 88 & 90 & 90 & 90 & 91 & 68 \\
\hline
\end{tabular}

LSD for germination in vitro between any treatments and time periods $(.01$ level $)=3.45$

LSD for emergence in sand between any treatments and time periods (.01 level) $=4.64$

LSD for field emergence between treatments after 12 months storage $(.01$ level $)=5.32$

' Nine, 13 and 17 = percent initial moisture content; $\mathrm{A}=$ ambient conditions at Mayagüez; $\mathrm{CS}=$ cold storage conditions at Lajas; $\mathrm{C}=$ cloth bag; and $\mathrm{P}=$ sealed plastic bag.

${ }^{2}$ Percentage seed germination in vitro, emergence in sand, and field emergence based on 3 replications of 100 seed per treatment and time period.

${ }^{3}$ Field emergence was recorded only after 12 -month storage.

For all seeds in cold storage, and seeds at 9 and $13 \%$ moisture sealed in plastic bags and stored under ambient conditions, there were no significant differences in either the percentage seed germination in vitro or emergence in sand when comparing the 2-mo and 12-mo sampling. All of the above mentioned treatments had at least $90 \%$ germination in vitro and $88 \%$ emergence in sand after 12-month storage (table 1). All treatments stored in cloth bags under ambient conditions had no significant differences in percentage germination whether in vitro or emergence in 
sand after 2-month storage. Germination in vitro and emergence in sand significantly decreased for all treatments in cloth bags under ambient conditions for each sampling date beginning at 4 mo. There was a significant decrease in percentage germination in vitro and emergence in sand at all sampling dates up to 10 months for seeds at $17 \%$ moisture in sealed plastic bags stored under ambient conditions. After 10 months, all seeds at $17 \%$ moisture in sealed plastic bags under ambient conditions were dead.

Seedling emergence in the field after 12-month storage was considerably lower than emergence in sand or germination in vitro for all treatments (table 1). There were no significant differences in percentage field emergence between all treatments in cold storage, and 9 and $13 \%$ moisture in sealed plastic bags under ambient conditions after 12-month storage. The percent field emergence for these treatments ranged from 68 to $72 \%$ after 12 mo. Seeds from all treatments stored in cloth bags under ambient conditions had significantly less emergence in the field than the previously mentioned treatments. There was no significant difference in percent field emergence between any treatments stored in cloth bags under ambient conditions. The percentage field emergence for all seeds stored in cloth bags under ambient conditions ranged from 16 to $19 \%$. Seeds at $17 \%$ moisture in plastic bags under ambient conditions did not emerge in the field. The reduction in percentage field emergence below percentage emergence in sand and germination in vitro cannot be explained from the results of this study, but is probably due to unfavorable field conditions for seedling emergence.

Seedborne fungi have been associated with decreased seed germination in storage $(1,3)$. In this study, seedborne fungi were not associated with reduced seed germination. The initial percentage of seeds infected by fungi was low (15\%). The percentage of seedborne fungi significantly decreased for all treatments between the 2- and 12-mo sampling dates. No treatment had over $2 \%$ incidence of seedborne fungi after 12 -month storage. Bacillus subtilis was associated with all dead seeds observed in this experiment. Bacillus subtilis has been reported to be associated with reduced seed viability of soybean in storage (2).

Seed moisture content and storage temperature are critical factors in the long term (1 year) storage of pigeon pea seed. When seed moisture content was dried to 9 and $13 \%$, then maintained at that level by placement of seeds in an air-tight container, seeds were successfully stored for 1 year under ambient conditions at Mayagüez (germination in vitro maintained at $90 \%$ ). Seeds at high moisture content (over 13\%) lost viability rapidly under ambient conditions. When seeds with over $13 \%$ moisture were placed in cold storage $\left(13^{\circ} \mathrm{C}\right)$, they were successfully stored for 1 year. 
The results of this study indicate that successful seed storage of pigeon pea can be accomplished without conditioned (dehumidified and refrigerated) storage. Low level technology can be employed in seed storage. The elimination of dehumidification and refrigeration equipment could result in reduced storage costs and a reduction in problems associated with equipment maintenance.

\section{RESUMEN}

El porcentaje de humedad en las semillas del gandul fue ajustado a 9 , 13 y $17 \%$. Luego se colocaron en bolsas de tela o bolsas plásticas selladas. Las semillas a los niveles de humedad arriba mencionados y colocadas en ambos tipos de bolsa, se almacenaron en condiciones ambientales en Mayagüez y en un frigorílfico $\left(13^{\circ} \mathrm{C}\right)$ en Lajas. En los tratamientos de almacenamiento refrigerado, después de 12 meses, el porcentaje de germinación in vitro, de brotadura tanto en arena como en el campo fue de $90-92 \%, 88-92 \%$ y $70-72 \%$, respectivamente. Todos los tratamientos almacenados en bolsas de tela por 12 meses en condiciones ambientales, tuvieron un porcentaje de germinación in vitro, y de brotadura en arena y en el campo de $36-37 \%$, 32-34\% y $16-17 \%$, respectivamente. No hubo diferencias significativas en el porcentaje de germinación in vitro o de brotadura en arena y en el campo entre las semillas almacenadas en condiciones ambientales a 9 y $13 \%$ de humedad en bolsas plásticas y las semillas almacenadas en frío. Las semillas almacenadas a $17 \%$ de humedad en bolsas plásticas y en condiciones ambientales estaban muertas luego de 10 meses de almacenamiento.

\section{LITERATURE CITED}

1. Christensen, C. M., 1972. Microflora and seed deterioration. In E. H. Roberts, Viability of Seeds. Syracuse University press. Chapter 3: 59-94.

2. Ellis, M. A., Tenne, F. D., and Sinclair, J. B., 1977. Effect of antibiotics and high temperature storage on decay of soybean seeds by Bacillus subtilis, Seed Sci. and Tech. 5: 753-761.

3. Fields, R. W. and King, T. H., 1962. Influence of storage fungi on deterioration of stored pea seed, Phytopathology 52: 336-339.

4. Grabe, D. F., 1965. Storage of soybeans for seed, Soybean Digest 26: 14-16.

5. Holman, L. E. and Carter, D. G., 1952. Soybean storage in farm-type bins, Illinois Agri. Exp. Stn. Bull. 553.

6. McNeal, X., 1966. Conditioning and storage of soybean, Arkansas Agri. Exp. Stn. Bull. 714. 